\title{
Widening the Wage Gap: The Skill Premium and Technology
}

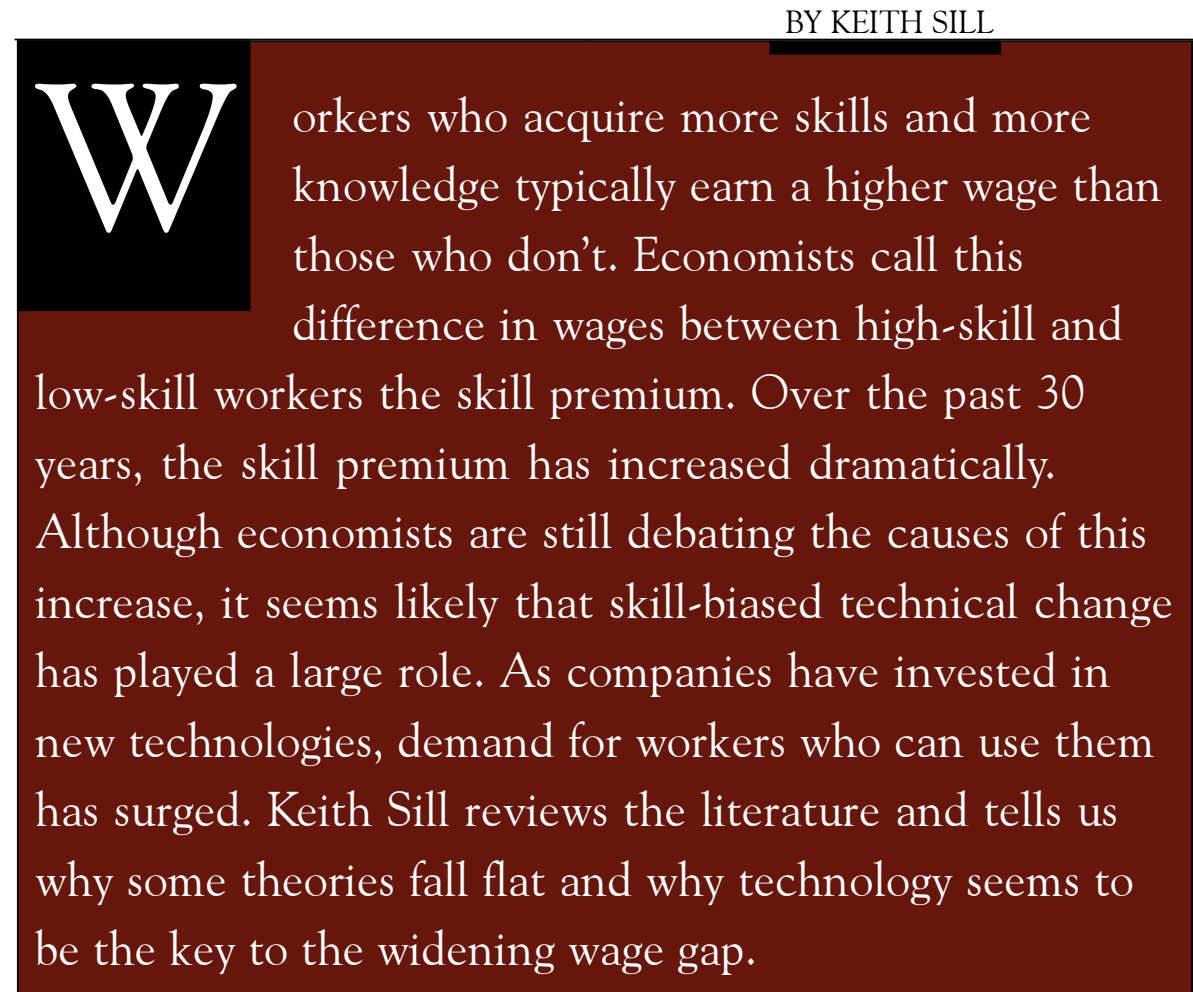

Data on earnings and wages show that workers receive a monetary reward for attaining high levels of skills and that this reward has been increasing over time. In fact, over the past 30 years, the wages paid to the most highly skilled workers - those who have higher levels of education, ability, or job training have increased dramatically relative to the wages of the least skilled workers. This difference in wages between skilled and unskilled workers is called the skill premium.

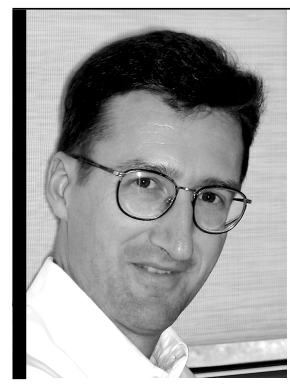

Keith Sill is a senior economist in the Research Department of the Philadelphia Fed.
Workers have responded to these monetary incentives by acquiring more skills through schooling. From the 1970s to the mid-1990s, the number of college-educated workers in the United States almost doubled, and they now represent a much larger share of the workforce. If we equate skill with college education, the supply of skilled workers was increasing dramatically at the same time that the skill premium was rising. We might think that a greater supply of skilled workers would lower wages for those workers, thereby lowering the return to acquiring skills and the skill premium. But since the supply of skilled workers increased dramatically at the same time that the skill premium increased - and supply increased even more rapidly in the 1980s - demand for skilled workers must also have increased.
In this article, I will examine theories and evidence that shed light on the dramatic increase in the skill premium over the past three decades. Explanations that have been proposed to account for the increase include the decline in the fraction of the labor force that is unionized and increased wage competition from unskilled workers in less developed countries. However, these theories are unable to explain important facts about the skill premium. Rather, the increased relative wage paid to skilled workers appears to be linked to new technologies that firms are using and to investments that firms are making in new equipment that embodies new technologies. For firms to take full advantage of this new equipment, they need high-skill workers to design, install, operate, and maintain it. At the same time, this new equipment often performs tasks that unskilled workers used to perform. As the economy has become more knowledge based, the demand for skilled workers has surged.

\section{ESTIMATING SUPPLY}

We can roughly estimate the supply of skilled workers by examining educational attainment. Generally, we consider workers with a college degree to be skilled and those with no college education to be unskilled. To account for workers who have some college education but no degree, we divide those workers evenly between skilled and unskilled workers. This measure of skilled workers is called college-equivalent workers. The relative supply of skilled (that is, college-equivalent) workers rose from 17 percent of the labor 
force in 1960 to about 43 percent in 1996 (Figure 1). There was slightly faster growth in the supply of collegeequivalent workers in the 1970s.

\section{MEASURING THE RETURN TO ACQUIRING SKILLS}

There are several ways to measure the extent to which the disparity in wages between skilled and unskilled workers has been increasing in the U.S. economy. Often, analysts focus on the average wages of skilled workers and compare them to the average wages of unskilled workers. The higher the disparity in wages between skilled and unskilled workers, the higher is the skill premium.

Returns to Education. A higher level of education is one way that workers can upgrade their skills and increase their wages. Thus, we can examine how the return on earnings from acquiring more education has changed over time, since, generally, the return to years of schooling tracks changes in the wage structure. For example, we can study how earnings tend to increase after a worker spends another year in college. A 1999 paper by Claudia Goldin and Lawrence Katz examined the returns to education for U.S. workers. The return to education is measured as the percent increase in wages, calculated at an annual rate, that workers with more education get compared with workers with less education. Goldin and Katz found that the return to a year of college education for young men fell slightly, from 9.6 percent in 1969 to 8.4 percent in 1979, then shot up to 13.3 percent in $1995 .{ }^{1}$ Thus, workers who acquire more

\footnotetext{
1 The return to a year of college is defined as the natural $\log$ of the ratio of mean wages for those with exactly 16 years of schooling and those with exactly 12 years of schooling divided by 4 . The wage data were adjusted for workers' experience and geographic differences. See Goldin and Katz's 1999 paper for details.
}

\section{FIGURE 1}

\section{Supply of Skilled Workers}

$\%$
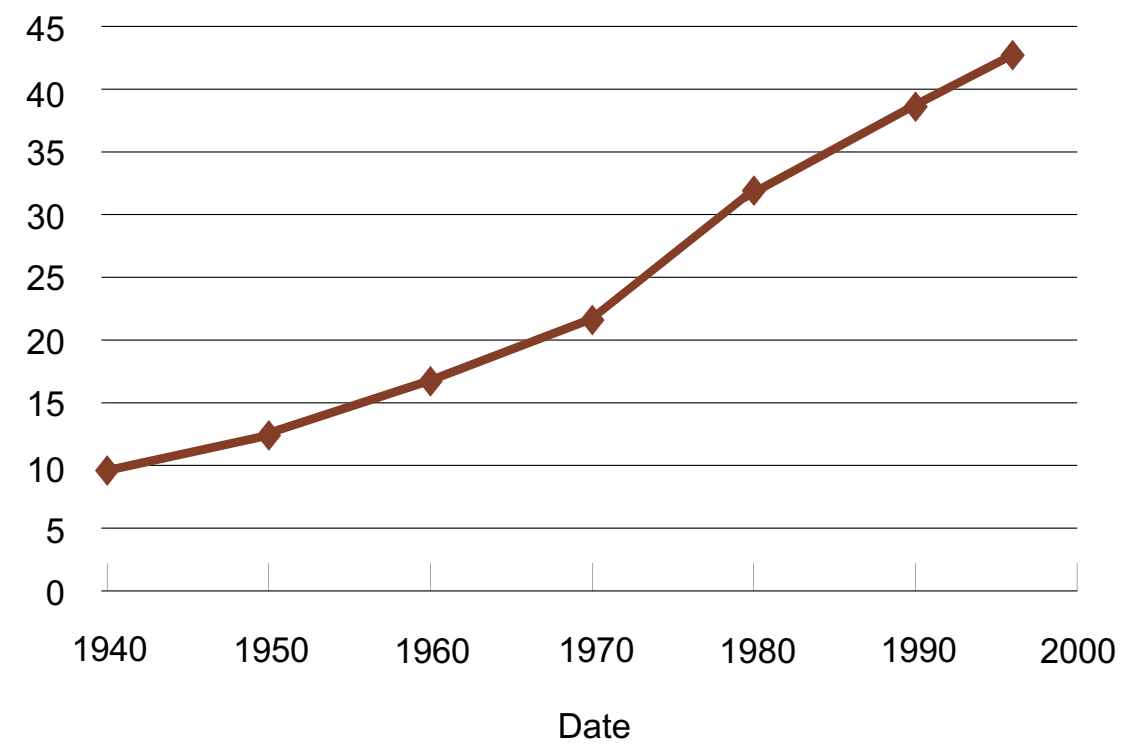

* Supply of college-equivalent workers as a fraction of the labor force. College equivalent workers are defined as workers with a college degree plus 50 percent of workers with some college education. Data taken from Table 1 in David H. Autor, Lawrence F. Katz, and Alan B. Krueger, "Computing Inequality: Have Computers Changed the Labor Market?" The Quarterly Journal of Economics, 113:4 (November 1998), pp. 1169-1213. (C) 1999 by the President and Fellows of Harvard College and the Massachusetts Institute of Technology. Used with permission.

education and improve their skills receive a greater return from that education today than they did in the 1960s. This suggests that earnings inequality between high-education and low-education workers has risen compared with what it was in 1969. Data for 1999 show that having more education tends to pay off: The average earnings of high-school-educated workers were $\$ 24,572$, compared with average earnings of $\$ 45,678$ for collegeeducated-workers and $\$ 67,697$ for workers with advanced degrees. ${ }^{2}$

We can also directly compare the wages of workers who went to college and those who did not. The average wage of a college-educated worker was about 59 percent higher

${ }^{2}$ For more on recent trends in the dispersion of wages, see the article by Bharat Trehan. than that of a high-school-educated worker in 1970 and about 75 percent higher in 1996. The skill premium began to rise dramatically beginning around 1980 (Figure 2). ${ }^{3}$ More recent data suggest that the skill premium continued to rise from the mid-1990s through 2000.4

Distribution of Wages. Other measures of wage disparity tell a similar story. We can summarize wage disparity by examining the distribution of wages across workers, which shows the frequency with which wages of a

\footnotetext{
${ }^{3}$ These numbers are based on those in the paper by David Autor, Lawrence Katz, and Alan Krueger. They report that the natural $\log$ of the ratio of a weighted average of college and post-college wages to high-school wages was 0.465 in 1970 and 0.557 in 1996.

${ }^{4}$ See the paper by Paul Beaudry and David Green.
} 


\section{FIGURE 2}

\section{College Skill Premium*}

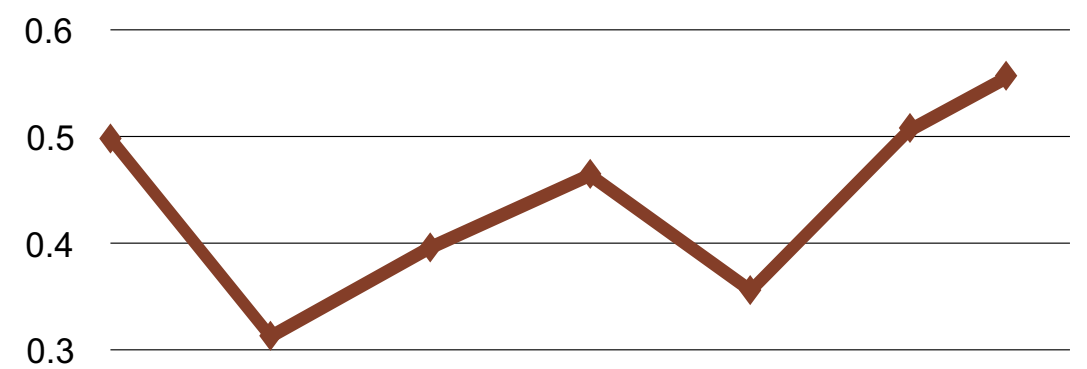

0.2

0.1

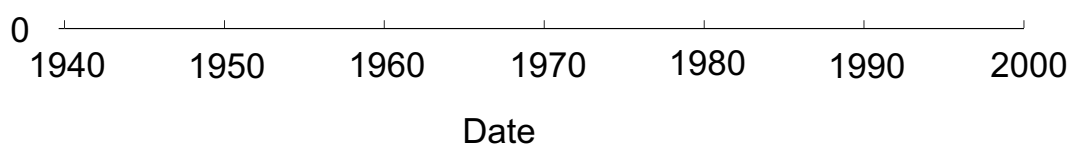

* Log relative wage of college plus post-college workers to high-school workers. Last point plotted is for 1996. Data from Autor, Katz, and Krueger.

\section{FIGURE 3}

\section{Indexed Wages for White Males 1963-1997*}

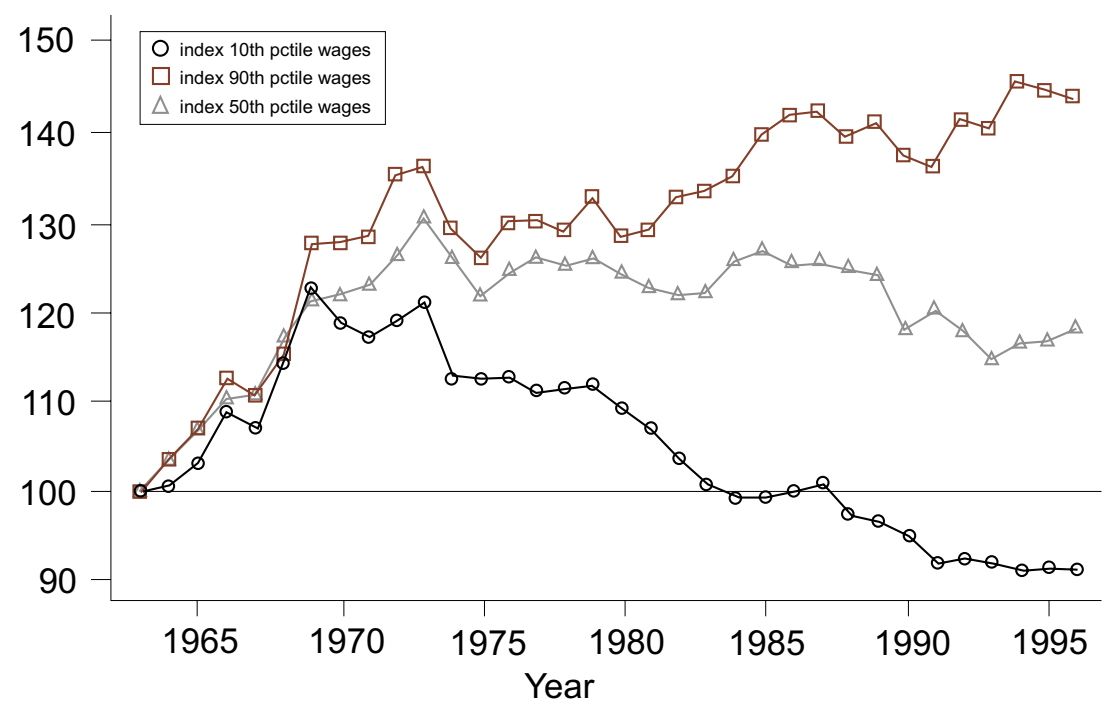

${ }^{*}$ Changes in the indexed value of the 90th, 50th, and 10th percentiles of the wage distribution for white males (1963 values normalized to 100). Data from March CPSs.

Figure taken from Daron Acemoglu, "Technical Change, Inequality, and the Labor Market," Journal of Economic Literature, 40, 1, 2002 (Figure 2). Used with permission.

certain level are likely to occur in the population of workers. For example, we would expect to find relatively few workers who make over $\$ 200,000$ a year, but many more workers who make around $\$ 40,000$ a year. We can then use this distribution to examine how the wages of the richest and poorest workers change over time. In fact, the wage differential between workers whose earnings are in the top 10 percent of the wage distribution (the richest workers) and workers whose earnings are in the bottom 10 percent of the wage distribution (the poorest workers) has increased dramatically since the 1970s. So has the wage differential between the average worker $\left(50^{\text {th }}\right.$ percentile) and workers in the lowest $10^{\text {th }}$ of the distribution. Wages of high-earning white males and lowearning white males rose in tandem during the 1960 s (Figure 3). ${ }^{5}$ Beginning in the 1970s, wages began to diverge. By 1995 , top earners' wages were about 40 percent higher than they were in the early 1960s (that is, the index rose to 140), while earners at the bottom of the distribution saw real wages fall 10 percent (the index fell to 90). Workers in the middle of the distribution fared somewhat better than those at the bottom: The average worker saw his wage rise about 15 percent from the early 1960s until 1995.

\section{EXPLAINING THE INCREASE IN THE SKILL PREMIUM}

The rise in the skill premium could be due to rising wages for skilled workers or falling wages for unskilled workers, or both. The data show that the real wages (wages adjusted for inflation) of skilled workers generally have risen since the mid-1970s. However, the real wages of unskilled workers

${ }^{5}$ We look at white males to control for changes in demographics over time, such as the increasing share of women in the labor force. A change in the index represents a percent change from 1963, the base year for the index. 
fell from the mid-1970s to the early 1990s, then began to rebound. Thus, part of the story for the rise in the skill premium since the 1970s is that real wages for unskilled workers fell over much of the period.

Several theories have been

proposed to account for the increase in the skill premium in the United States.

Globalization. One commonly proposed explanation highlights globalization and increased trade with less developed countries. In less developed countries, low-skill workers are more abundant than high-skill workers because workers in poor countries tend to have less training and education and to work in industries not as technically advanced as those in developed countries. When the U.S. increases its trade of goods and services with less developed countries, the lowskill workers in poor countries put downward pressure on the wages of lowskill workers in the U.S., since the two sets of workers often produce comparable items. Similarly, the goods that high-skill workers produce in the U.S. are scarce in less developed countries. So when less developed countries import more of those goods, demand increases, and there is upward pressure on the wages of high-skill workers in the U.S.

Empirical support for the globalization theory is weak, though. For the U.S., trade with less developed countries represents, at most, 2 percent of gross domestic product (GDP). Because it contributes such a small part to U.S. GDP, trade with less developed countries is unlikely to be driving the trend in the skill premium. Furthermore, the trade-liberalization story implies that the prices of less skill-intensive goods in the U.S. economy should fall relative to the prices of more skill-intensive goods because the U.S. would import the goods produced by low-skill foreign labor and export goods produced by high-skill U.S. labor. But the data contain little evidence for this price behavior.

If trade were the main force

behind the rise in the skill premium, we would find that increased production of skill-intensive goods (to meet increased demand for these goods from foreign countries) would be drawing workers increased wage inequality is the subject of much research.?

In the United States, the big decline in unionization came during the 1980s, after the defeat of the air-traffic controllers' strike. This large drop in unionization occurred after the rapid

\section{The rise in the skill premium could be due to rising wages for skilled workers or falling wages for unskilled workers, or both.}

away from other sectors of the economy. However, some studies have indicated that all sectors, even those that produce less skill-intensive goods, have increased their demand for skilled workers, that is, production of many goods is becoming more skill-intensive. ${ }^{6}$ Thus, we do not see the across-industry shift in employment implied by the trade story.

Decline in Unionization.

Another theory that has been proposed to explain the rise in the U.S. skill premium is that the fraction of the workforce that is unionized has been declining for some time. Union contracts tend to be written in such a way that the difference in wages between the highest and lowest paid workers is less than what it would be if there were no unionization. For example, some union contracts may tie salary increases more to tenure on the job than to merit.

Unions had set wages for many occupations in the postwar U.S. However, the fraction of the civilian labor force that is unionized peaked at about 25 percent around 1970, then fell to about 13 percent in the early 1990s. Could this decline in unionization have contributed significantly to the increase in wage inequality? The theory that the decline in unionization has caused

${ }^{6}$ See the article by Berman, Bound, and Griliches and the one by Autor, Katz, and Krueger. increase in the skill premium in the 1960s. Note, though, that the decline in unionization does coincide with the drop in wages of unskilled workers, and so it may be a contributing factor in the rise in the skill premium. One difficulty with the unionization theory is that wage inequality (the difference between the highest paid workers and the lowest paid workers) has also increased in many professions, such as medicine and law, that are not generally unionized. Evidence from other countries, such as the United Kingdom and Canada, also shows little correlation between the extent of unionization and trends in wage inequality. Thus, while the decline in unionization may have been a contributing factor to the increase in the skill premium in the U.S., it does not appear to be a primary explanation. $^{8}$

Advances in Technology. The most promising theory to account for the rise in the skill premium ties the

7 A readable discussion of such research is Martin Asher and Robert DeFina's 1995 Business Review article.

${ }^{8}$ Another potential explanation for the rise in the skill premium and the fall in wages of lowskill workers is immigration. Immigrants have tended to be low-skill workers; thus, an influx of these workers may have depressed wages of other low-skill workers. However, empirically, immigration's effect on the skill premium appears to be small. See the paper by George Borjas, Richard Freeman, and Lawrence Katz. 
change in wages to the advancement of technology. When advances in technology increase demand for skilled workers more than demand for unskilled workers, economists say that technical change is skill-biased.

New technologies are constantly being developed, and firms have been investing heavily in equipment that uses these new technologies. The new high-tech equipment, such as computer-controlled machines, industrial robots, and flexible manufacturing systems, performs more efficiently in the hands of skilled workers. As this advanced technology becomes more common in the workplace, it tends to replace unskilled workers; at the same time, it requires additional skilled workers to operate it.

Directly measuring the amount of technological progress in the U.S. economy is difficult. Indirect measures, such as the amount of spending on research and development and the amount of spending on computers, are available. A 1994 study by Eli Berman, John Bound, and Zvi Griliches found that spending on research and development and computers accounts for about 70 percent of the shift of the manufacturing labor force from production workers to nonproduction workers from 1979 to 1987. Conceptually, production workers are typically associated with "blue-collar" jobs and nonproduction workers with "white-collar" jobs. ${ }^{9}$ In addition, the classification of workers into blue-collar

\footnotetext{
9 The paper by Berman, Bound, and Griliches uses the Annual Survey of Manufactures' definition of production workers: "workers (up through the working foreman level) engaged in fabricating, processing, assembling, inspecting, and other manufacturing." Nonproduction workers are "personnel, including those engaged in supervision (above the working foreman level), installation and servicing of own product, sales, delivery, professional, technological, administrative, etc."
}

and white-collar jobs closely reflects their classification into those with a high-school education and those with a college education. Hence, the shift from production workers to nonproduction workers indicates a shift from low-skill to high-skill workers. By this measure, spending on new technologies has helped boost demand for skilled workers.

\section{For the most part, new technologies that were introduced in the $20^{\text {th }}$ century tended to replace unskilled workers and favored the use of skilled workers.}

Other studies have found that the share of college-educated workers has increased substantially in all sectors of the economy since the mid-1970s. ${ }^{10}$ The demand for skilled workers must have been increasing even faster than the supply, however, since the skill premium has been rising.

The data suggest that new technologies, new capital (machines), and skilled labor go together and that new machines are more likely to replace unskilled workers. As firms invest in new technologies, the demand for skilled workers increases relative to the demand for unskilled workers, and the

${ }^{10}$ Berman, Bound, and Griliches found that the shift of workers from production tasks to nonproduction tasks is happening within industries. Thus, many industries increased their demand for skilled workers as a result of advancements in technology; it is not the case that the main driver has been a shift from low-tech to high-tech industries. Autor, Katz, and Krueger's research also confirms this finding. relative wage paid to skilled workers rises.

Remember, though, that not only have the wages of skilled workers increased, but also those of unskilled workers have decreased. Can technological change lead to lower wages for unskilled workers at the same time that it increases wages for skilled workers? Under certain conditions, the answer is yes. Suppose there are two production sectors in the economy: One sector uses capital and skilled workers to produce goods, and the other uses capital and unskilled workers. A new technology that works well with skilled labor might induce a flow of capital from the sector with unskilled workers to the one with skilled workers in order to take advantage of skilled workers' increased productivity. As capital flows out of the unskilled sector, workers in that sector will have less capital to work with, making them less productive and leading to a decline in wages paid to unskilled workers. Hence, technical change that favors skilled workers could lead to a drop in the wages of unskilled workers and a simultaneous rise in the wages of skilled workers. ${ }^{11}$

\section{THE SKILL PREMIUM SURGED IN THE 1980s}

If changes in technology explain the increase in the skill premium, the next question is: Did changes in technology accelerate in the 1980s and lead to a surge in the skill premium in that decade?

Historical studies have found that skill-biased technical change was prevalent throughout the $20^{\text {th }}$ century. For the most part, new technologies that were introduced in the $20^{\text {th }}$ century tended to replace unskilled workers and favored the use of skilled workers. In their 1998 article, Claudia Goldin and

\footnotetext{
${ }^{11}$ See the paper by Beaudry and Green.
} 
Lawrence Katz argue that new manufacturing technologies that replaced unskilled workers and increased the demand for skilled workers became prevalent with the introduction of batch and continuous-process methods of production in the early $20^{\text {th }}$ century. ${ }^{12}$ Similarly, the switch from steam and water power to electrical power reduced the demand for unskilled workers in many transportation and assembly tasks. More recent examples of new technologies that have replaced unskilled labor include robotic assembly operations and programmable machine tools.

But if skill-biased technical change was occurring throughout the $20^{\text {th }}$ century, potentially raising the relative wages of skilled workers versus those of unskilled workers, how do we account for the dramatic increase in wage inequality over the past 20 years? Figure 2 shows that the rise in the skill premium was particularly large in the 1980s. Why?

Accelerating Demand. Did skill-biased technical change accelerate in the 1980s and boost demand for skilled workers? Several pieces of indirect evidence suggest this may be the case. Studies have found that almost all industries began to employ more educated workers in the 1970s and 1980s. Furthermore, industries that used computers more intensively experienced more rapid upgrading in the skills of their workforces. ${ }^{13}$ However, it is not clear that advances in computers and information technology increased the demand for skilled workers more rapidly than other new technologies did in the

\footnotetext{
12 Batch processes are used for processing liquid and gaseous materials such as chemicals, wood pulp, and dairy products. Continuous-process methods are used for products that require little assembly and have few moving parts such as canned foods, soap, and cigarettes. See Goldin and Katz 1998.

${ }^{13}$ See the paper by Autor, Katz, and Krueger.
}

1950s and 1960s. In other words, we cannot conclude just by looking at patterns of computer use that demand for skilled workers has accelerated.

Autor, Katz, and Krueger provided evidence in support of an accelerating demand for skilled workers. They compared data on the skill premium and the supply of skilled workers during two periods: 1940 to accelerated as firms responded to the price incentive to invest more in new capital equipment. ${ }^{15}$

Total Factor Productivity. One caveat in tying the rise in the skill premium to advances in technology and the associated investment in high-tech goods is the behavior of measured technological progress. Has technology advanced at a more rapid pace since the

\section{We cannot conclude just by looking at patterns of computer use that demand for skilled workers has accelerated.}

1970 and 1970 to 1995 . The period from 1940 to 1970 was characterized by slow growth of both the skilled labor supply and the skill premium. From 1970 to 1995, both the supply of skilled workers and the skill premium grew rapidly. If demand for skilled workers had not accelerated, we would expect the skill premium to have grown more slowly from 1970 to 1995 than over the earlier period, since the supply of skilled workers was growing faster in the later period.

Other evidence is consistent with the view that skill-biased technical change has accelerated. The data suggest that new capital equipment has become cheaper. This new equipment often replaces unskilled workers because it can perform tasks they previously did. In addition, adding new capital equipment to the workplace means that firms must hire skilled workers to use, operate, and maintain it. As the price of new capital equipment falls, firms acquire relatively more of it, boosting demand for skilled labor and decreasing demand for unskilled labor. Data on the price of new equipment suggest that the decline in price accelerated at the beginning of the 1970s. ${ }^{14}$ Hence, the demand for skilled workers may have 1970s? A broad measure of technical change is total factor productivity (TFP) growth. TFP growth, growth in capital stock, and growth in total hours worked in production are combined to determine output growth, and TFP is the part of output growth unexplained by growth in capital stock and the labor force. In the data, though, measured TFP growth did not surge upward during the period in which the skill premium shot up, casting some doubt on the view that technical progress has accelerated since the 1970 s. $^{16}$

\footnotetext{
14 See the article by Per Krusell, Lee Ohanian, Victor Rios-Rull, and Giovanni Violante.

15 There are reasons to be cautious about this story of more rapid investment. It is very hard to accurately measure the price of equipment that is undergoing rapid technological advance. Take the case of computers. The change in the quality of computers over time makes it difficult to quantify exactly how much cheaper computers are today than they were in the past. Difficulties in consistently measuring the price of new equipment over time make it harder to be confident that the decline in the relative price of new equipment accelerated in the 1970s, thus increasing investment. It certainly does seem plausible, though.

${ }^{16}$ For more information about TFP, see the article by Satyajit Chatterjee.
} 
Is the lack of evidence for faster TFP growth a nail in the coffin for technology-driven gains in the skill premium? Possibly not, given that true TFP growth is hard to measure. One consequence of rapid technological advance is that prices may be hard to measure accurately over time. And those difficulties may increase over time as technology grabs an increasingly larger share of the economy. If price inflation is overstated, measured real output growth and measured TFP growth will be understated. Thus, the lack of evidence for faster TFP growth since the 1970s may be a result of the way government statistics track prices over time. ${ }^{17}$

\section{WHY HAS SKILL-BIASED TECHNICAL CHANGE ACCELERATED?}

Notwithstanding the caveats mentioned above, the weight of the evidence seems to suggest that skillbiased technical change accelerated during the 1980s for the U.S. economy. Why? Several theories have been put forward. One possibility, explored in a 1998 article by Daron Acemoglu, is that designers and implementers of new technologies, such as scientists and engineers, recognized that the relative supply of skilled workers had increased, then developed technologies that took advantage of the increasingly skilled workforce. Perhaps engineers specifically designed new machines in a way that could better use the abilities of skilled workers. Economists call this theory directed technical change. An attractive feature of this story is that it gets the timing right between the increase in the

${ }^{17}$ An in-depth discussion of many of the issues surrounding these measurement difficulties and their implications for economic growth can be found in the 1997 Business Review article by Leonard Nakamura. number of skilled workers and the increase in the skill premium - they showed faster growth at about the same time.

However, we should be cautious in using the theory of directed technical change to interpret the recent facts because another important episode in U.S. history seems to contradict the theory's predictions. During the 1940s, there was a surge in the supply of highschool-educated workers, who were the skilled workers of that time. But the data show no dramatic increase in the wages paid to high-school-educated workers in the 1940s. ${ }^{18}$ Why didn't the engineers of the 1940s design new diffuse through the economy, but they eventually lead to an increase in worker productivity. Early examples of GPTs include the invention of writing, typesetting, and printing, and the development of electric motors.

If the computer and communications revolution is an example of GPT that slowly diffused through the economy, could it explain the acceleration of skill-biased technical change and the effect of that acceleration on wages? It is likely that it takes time for firms and workers to learn to use new technologies in the most efficient manner. When computers and new software were first introduced, there was a steep learning

\section{The weight of the evidence seems to suggest that skill-biased technical change accelerated during the 1980s for the U.S. economy.}

equipment that used the relatively abundant supply of skilled workers and thus increase demand for skilled workers more than enough to offset the increase in supply?

Another story that potentially explains the acceleration of skill-biased technical change is related to the computer and communications revolution and the extent to which it has affected many different sectors of the economy. The computer and communications revolution that began in the 1970s may be an example of what economists call a general purpose technology (GPT). A GPT is an innovation that has the potential to become widely used across many sectors of the economy and that drastically changes the way businesses and factories in the affected sectors carry out their operations. GPTs may be slow to

${ }^{18}$ See the 1999 paper by Goldin and Katz. curve as workers learned to use them effectively. Measured productivity may have declined as workers learned because time was allocated away from directly productive tasks and into learning the new technology. Once firms and their workers became comfortable with the new technology and discovered effective ways to use it in production, productivity growth began to increase. At the same time, the demand for workers who could use the new technology rose. If demand accelerated more than supply, the skill premium paid to high-skill workers would have tended to rise. ${ }^{19}$

\section{CONCLUSION}

Which of these stories directed technical change or GPT or perhaps an entirely different one - best fits the facts remains an open question.

${ }^{19}$ See the article by Philippe Aghion. 
What is clear is that wage inequality increased over the 1980s and even accelerated relative to its historical trend.

In their 1999 paper, Goldin and Katz claimed that "economic inequality is higher today than at any time in the past 60 years, measured by both the

\section{REFERENCES}

Acemoglu, Daron. "Technical Change, Inequality, and the Labor Market," Journal of Economic Literature, 40, pp. 7-72, 2002.

Acemoglu, Daron. "Why Do New Technologies Complement Skills? Directed Technical Change and Wage Inequality," Quarterly Journal of Economics 113, 1998, pp. 1055-90.

Aghion, Philippe. "Schumpeterian Growth Theory and the Dynamics of Income Inequality," Harvard University Mimeo, 2001.

Asher, Martin A., and Robert H. DeFina. "Has Deunionization Led to Higher Earnings Inequality?” Federal Reserve Bank of Philadelphia Business Review (November/ December 1995).

Autor, David H., Lawrence F. Katz, and Alan B. Krueger. "Computing Inequality: Have Computers Changed the Labor Market?" Quarterly Journal of Economics 113, 1998, pp. 1169-213.

Beaudry, Paul A., and David A. Green. "Changes in U.S. Wages 1976-2000:

Ongoing Skill Bias or Major Technological Change?" NBER Working Paper 8787 , February 2002. wage structure and wealth inequality." We have seen that demand for skilled workers rose dramatically in the 1980 s. For policymakers to effectively address concerns about inequality created by the widening wage gap between skilled and unskilled workers, they must understand its potential causes.
Our discussion and review of the literature suggest that skill-biased technical change is likely an important part of the story of rising wage inequality. If so, policies that focus on helping workers acquire skills are a good place to begin in addressing concerns about inequality.
Berman, Eli, John Bound, and Zvi Griliches. "Changes in the Demand for Skilled Labor Within U.S. Manufacturing: Evidence From the Annual Survey of Manufactures," Quarterly Journal of Economics, 109, 1994, pp. 367-97.

Borjas, George J., Richard B. Freeman, and Lawrence F. Katz. "Searching for the Effect of Immigration on the Labor Market," American Economic Review 86:2, 1996, pp. 246-51.

Bound, John, and George Johnson. "Changes in the Structure of Wages in the 1980s: An Evaluation of Alternative Explanations," American Economic Review 82:3, 1992, pp. 371-92.

Chatterjee, Satyajit. "Productivity Growth and the American Business Cycle," Federal Reserve Bank of Philadelphia Business Review, September/October 1995, pp. 13 22.

Goldin, Claudia, and Lawrence F. Katz.

"The Returns to Skill Across the Twentieth Century United States," Working Paper, Harvard University, 1999.
Goldin, Claudia, and Lawrence F. Katz.

"The Origins of Technology-Skill Complementarity," Quarterly Journal of Economics 113, 1998, pp. 693-732.

Katz, Lawrence F., and Kevin M. Murphy. "Changes in Relative Wages, 1963-1987: Supply and Demand Factors," Quarterly Journal of Economics 107, 1992, pp. 35-78.

Krusell, Per, Lee Ohanian, Victor Rios-Rull, and Giovanni Violante. "Capital Skill Complementarity and Inequality," University of Rochester mimeo, 2000.

Nakamura, Leonard. "Is the U.S. Economy Really Growing Too Slowly? Maybe We're Measuring Growth Wrong," Federal Reserve Bank of Philadelphia Business Review (March/April) 1997.

Trehan, Bharat. "Technical Change and the Dispersion of Wages," Federal Reserve Bank of San Francisco Economic Letter, 2002-23, August 2002. 